\title{
COMMUNITY DEVELOPMENT FOR MATERNAL HEALTH TROUGH PREGNANT MOTHER CLASS PROGRAM IN KLATEN, CENTRAL JAVA
}

\author{
Sri Panuntun ${ }^{1)}$, Ravik Karsidi²), Bhisma Murti3), Muhammad Akhyar²) \\ 1)Doctoral Program in Health Promotion/ Community Development, \\ Sebelas Maret University \\ 2)Faculty of Teaching and Education Sciences, Sebelas Maret Unversity \\ 3)Masters Program in Public Health, Sebelas Maret University
}

\begin{abstract}
Background: Pregnant women class (Kelas Ibu Hamil, KIH) activities have been implemented since 2009. It aims to improve maternal and child health, by providing a forum for health education and sharing information on maternal and child health. However, participation in $\mathrm{KIH}$ in Klaten, Central Java, was as low as 30\%. The purpose of this study was to evaluate the implementation of $\mathrm{KIH}$ program, by identifying problems and potential resources available within and outside the community, that can be used to develop a community development model to help support the development and improvement of KIH program.
\end{abstract}

Subjects and Method: This was a qualitative study with some complementary quantitative information. The study was carried out in North Klaten Subdistrict, Klaten, Central Java. The informants for this study were selected to include pregnant mothers, health cadres, village midwifes, midwife coordinators, health personnel at community health center, $\mathrm{KIH}$ programmers at district health office, and village community leaders. The data were collected by in-depth interview, direct observation, focus group discussion (FGD), and document review.

Results: Program implementation of KIH proceeded along the managerial steps, which included planning, implementation, monitoring, evaluation, and sustainability of program. The KIH program involved pregnant mothers, health cadres, village midwives, and midwife coordinators, which were under the control and reponsibility of the community health center, i.e. North Klaten health center. KIH meetings were funded by several budget sources, including Operational Health Assistance/ Bantuan Operasional Kesehatan (BOK), Revenue and Expenditure Budget of Provincial Government (APBD I), and for the last one year Village Fund Alocation (ADD). Implementation of $\mathrm{KIH}$, however, was still midwife oriented. Pregnant mother participation was only $36.30 \%$. KIH activities were held at posyandu, sub health center, and village office, mostly in the morning for 2 hour duration. Implementation of KIH faced some problems, which stemmed from social, economic, cultural, human resource, technical, and policy problems. The problems that had inhibited the progress of $\mathrm{KIH}$ included the lack of facilitator creativity, absence of former $\mathrm{KIH}$ participation involvement, shortage of community understanding on the importance of participation, inaccurate use of village fund allocation budget, irregular monitoring and evaluation.

Conclusion: Some initiatives are suggested to be taken in order to correct problems and to improve implementation of KIH. 
Keywords: community development, pregnant women class, participation

Correspondence: Sri Panuntun. Doctoral Program in Health Promotion/ Community Development, Sebelas Maret University, Jl. Ir. Sutami 36 A, Surakarta 57126, Central Java. Email: ichakuo6@yahoo.com. 